\title{
Insomnia és elalvást segítő szokások felmérése felnőttek körében
}

\author{
Fusz Katalin ${ }^{1,2}$ - Faludi Béla dr. ${ }^{3}$ - Pusztai Dorina ${ }^{1}$ \\ Sebők Nóra ${ }^{1}$. Oláh András dr. ${ }^{1}$ \\ Pécsi Tudományegyetem, ${ }^{1}$ Egészségtudományi Kar, Ápolástudományi, \\ Alapozó Egészségtudományi és Védőnői Intézet, ${ }^{2}$ Egészségtudományi Doktori Iskola, \\ ${ }^{3}$ Általános Orvostudományi Kar, Klinikai Központ, Neurológiai Klinika, Pécs
}

A szerzők cikküket a Pécsi Tudományegyetem alapitásának 650. évfordulója tiszteletére közlik.

\begin{abstract}
Bevezetés: Az alvásminőséget számos tényező befolyásolhatja, az insomnia pedig hatással van az egészségi állapotra. Célkitüzés: Kutatásunk célja felmérni az insomnia gyakoriságát és hatásait, az alvást befolyásoló tényezőket és az elalvást segítő szokásokat felnőttek körében. Módszer: Az adatfelvétel országosan online és a dél-dunántúli régióban papíron történt, 455 felnőtt töltötte ki a kérdőívet, amelynek része az Athén Insomnia Skála. Eredmények: A vizsgálatban részt vevők 13,4\%-a insomniás. Az insomniát (átlagpont: 5,08) befolyásolja a táplálkozás minősége $(\mathrm{p}<0,001)$, a kávéfogyasztás $(\mathrm{p}=0,045)$ és a sport $(\mathrm{p}=0,011)$, továbbá összefüggésben van a krónikus betegségek $(\mathrm{p}=0,001)$ és a pszichoszomatikus panaszok gyakoriságával $(\mathrm{p}<0,001)$. Az alvászavar leggyakoribb okai: munkahelyi stressz $(35,6 \%)$, magánéleti stressz $(35,4 \%)$ és fájdalom $(24,2 \%)$. Akik a magánéleti stresszt $(\mathrm{p}=0,001)$ és fájdalmat $(\mathrm{p}=0,033)$ jelölték oknak, rosszabbul alszanak. Elalvási problémák esetén alkalmazott leggyakoribb szokások a tévénézés, az olvasás; a válaszadók 7,5\%-a alkalmaz altatószert és 11,4\%-a gyógyteát. Következtetések: Kutatásunkkal felhívjuk a figyelmet az insomnia gyakoriságára, hatásaira és az elalvást segítő lehetőségekre. Orv. Hetil., 2016, 157(49), 1955-1959.
\end{abstract}

Kulcsszavak: insomnia, egészségi állapot

\section{Insomnia and habits to help to fall asleep among adults}

Introduction: The quality of sleep can be influenced by several factors, insomnia in turn has an effect on the state of health. Aim: The aim of our survey is to measure the effects of insomnia, furthermore, the sleep affecting agents and habits to help to fall asleep among adults. Method: We collected the online nationwide and the written datas from the South-Transdanubia region, 455 adults filled the questionnaire which contains the Athens Insomnia Scale. Results: $13.4 \%$ of participants has insomnia, it is influenced by the quality of diet $(p<0.001)$, comsumption of coffee $(\mathrm{p}=0.045)$ and the physical activity $(\mathrm{p}=0.011)$, what is more in correlation with the prevalency of chronic deseases $(\mathrm{p}=0.001)$ and psychosomatic symptoms $(\mathrm{p}<0.001)$. The most frequent causes of sleep disorders are: work-related stress $(35.6 \%)$, personal-life stress $(35.4 \%)$ and pain $(24.2 \%)$. In case of dormition problems most of the participants watch television $(52.1 \%)$ and read $(33 \%) ; 7.5 \%$ and $11.4 \%$ of the responders use sleeping pills and tisane. Conclusions: We attract attention to the prevalency and effects of insomnia, and the habits to help to fall asleep.

Keywords: insomnia, state of health

Fusz, K., Faludi, B., Pusztai, D., Sebők, N., Oláh, A. [Insomnia and habits to help to fall asleep among adults]. Orv. Hetil., 2016, 157(49), 1955-1959.

(Beérkezett: 2016. augusztus 8.; elfogadva: 2016. szeptember 25.)

\section{Rövidítések}

AIS = Athén Insomnia Skála; WASM = World Association of Sleep Medicine
Az alvásnak elengedhetetlen élettani szerepe van szervezetünk fizikai és pszichés regenerációjában. A fiziológiás alvásmintázat kóros mennyiségi vagy minőségi változása, 
vagy az alvásciklus időbeni eltolódása sokféle következményhez vezethet. Kutatások bizonyítják, hogy az alvászavar rizikótényezője számos mentális és szomatikus megbetegedésnek [1-6], továbbá arra is felhívják a figyelmet, hogy nagyon gyakori probléma [7], ezek ellenére az alvászavarok felismerése és kezelése a betegellátás egy elhanyagolt területe [8]. Alvási elégtelenség, azaz insomnia akkor áll fenn, ha az elalvás és/vagy az alvás fenntartása zavart szenved, és nappali panaszokkal és életminőség-romlással jár. Komorbid insomnia esetén az alvászavar valamilyen pszichiátriai, szomatikus társbetegséggel, más alvásbetegséggel (például narcolepsia, parasomnia) vagy gyógyszerszedéssel és -abbahagyással jár együtt. A váltott múszakban dolgozók körében gyakori probléma az alvászavar a megzavart diurnalis ritmus következtében, esetükben társbetegségek nélküli insomniás tünetek jelentkezésekor cirkadiánritmus-zavarról beszélünk $[9,10]$.

Az alvászavar kezelésének három alappillére van: társbetegségek kezelése, nem gyógyszeres és gyógyszeres kezelés. Nem gyógyszeres kezeléshez tartozik az alváshigiénés tanácsadás, a pszichoterápia, a viselkedés- és kognitív terápiák, relaxáció, alváskorlátozás, fényterápia és fizikai aktivitás. A szakemberek felhívják a figyelmet az alváshigiénés szabályok fontosságára a pihentető, megfelelő minőségű alvás érdekében. Alapvető a rendszeresség a napirendben (munka, étkezés, lefekvés, felkelés stb.). Lehetőleg ne aludjunk délután, ne együnk túl sok és nehezen emészthető ételt este, valamint koffein- és alkoholtartalmú italok fogyasztása sem javasolt. A testmozgás is jótékony az alvászavar megelőzésében, kezelésében, azonban arra figyelni kell, hogy ne a lefekvés előtti órákban sportoljunk. A hálószoba, az ágy az alvást szolgálja, lehetóleg ne legyen televízió, számítógép a közelünkben; valamint az ébresztőóra se legyen látótávolságban. A kényelem is fontos, azaz a matrac minósége is befolyásoló lehet, továbbá a szoba hőmérséklete és a fényerősség is. Az elalvás előtti félórában megnyugtató tevékenységek, stresszcsökkentő módszerek alkalmazása lehet indokolt (relaxáció, ima stb.). Érdemes akkor lefeküdni, amikor tényleg álmosak vagyunk, így elkerülhető a felesleges hánykolódás $[3,10,11]$.

Vizsgálatunk célja volt felmérni az alvászavarok előfordulásának gyakoriságát és egyes befolyásoló tényezőit felnőttek körében. Vizsgáltuk továbbá az elalvási szokásokat, az alváshigiénét.

\section{Módszer}

\section{Minta}

Az adatfelvétel 455 magyar felnőtt bevonásával történt 2016-ban. A dél-dunántúli régióban, Pécsen, Szekszárdon és Osztopánban 208 fó töltötte ki a kérdőívet, míg az országos online felmérés keretében 247 -en. A válaszolási arány $70 \%$ körül mozgott.
A kérdőívet kitöltők 74,7\%-a nő ( $\mathrm{n}=340)$, az átlagéletkor 38,56 év (minimum: 17, maximum: 88; SD: 16). A válaszadók $50,4 \%$-a $(\mathrm{n}=229)$ házas vagy élettársi kapcsolatban él, 50 fó $(11,1 \%)$ él egyedül, 139 fó $(30,5 \%)$ gyermeket nevel. A leggyakoribb iskolai végzettség a szakközépiskola/gimnázium $(44,8 \%, \mathrm{n}=204)$.

\section{Méröeszköz}

Athén Insomnia Skála (AIS) [8, 12]: nyolc kérdésből álló skála, amelyben öt az éjszakai tüneteket méri fel (elalvási és átalvási nehézség, korai felébredés), három pedig a nappali következményekre kérdez rá. Minél magasabb a pont, annál rosszabb az alvásminőség (maximum 24 pont kapható). 10 pont esetén már klinikailag szignifikáns insomniát jelez a kérdőív.

\section{Statisztikai elemzés}

SPSS 20.0 ( $\chi^{2}$-, t-próba, ANOVA, Kruskal-Wallis-próba és lineáris regresszió alkalmazása). Az eredményt szignifikánsnak tekintettük, ha a $\mathrm{p}<0,05$.

\section{Eredmények}

\section{Munkavégzés, egészség-magatartás és egészségi állapot}

Az alvásminőséget befolyásoló tényezők közül megvizsgáltuk a munkavégzést, egészség-magatartást és az elalvási nehézség esetén alkalmazott szokásokat.

Felmértük a résztvevők foglalkoztatási státuszát, foglalkozását és munkarendjét. A válaszadók 63,5\%-a $(\mathrm{n}=289)$ dolgozik, 17,1\%-a $(\mathrm{n}=78)$ iskolába jár, 2,9\%-a ( $\mathrm{n}=13)$ munkanélküli, 9,5\%-a $(\mathrm{n}=43)$ nyugdíjas és $5,5 \%$-a $(n=25)$ van otthon gyermekével. A munkavállalók közül a legtöbben, 19,3\% irodai munkát végez $(\mathrm{n}=88), 13 \%$-uk ápoló $(\mathrm{n}=59)$, más egészségügyi beosztásban (például orvos, mentőtiszt, dietetikus) 21 személy dolgozik, fizikai munkát pedig 37 -en végeznek.

A résztvevők $45,5 \%$-a $(\mathrm{n}=206)$ nappali egy múszakos munkarendben, és mindössze $0,9 \%(\mathrm{n}=4)$ dolgozik állandó éjszakai múszakban, váltott múszakban pedig a válaszadók 18,5\%-a $(\mathrm{n}=84)$. Arra a kérdésre, hogy korábban dolgozott-e éjjel, a legtöbben nemmel válaszoltak (59,6\%). Az éjszakázáshoz kapcsolódóan megkérdeztük, milyennek ítélik a kronotípusukat. A válaszadók közül a legtöbben „inkább esti (bagoly)” típusúnak ( $\mathrm{n}=$ $145 ; 31,9 \%)$, míg a legkevesebben, 87 -en $(19,1 \%)$ „határozottan reggeli (pacsirta)" típusúnak tartják magukat.

Az egészség-magatartás kapcsán az alábbi eredményeket kaptuk. A legtöbben önbevallásuk alapján részben táplálkoznak egészségesen, de még jobban kellene figyelniük a táplálkozásra $(\mathrm{n}=209 ; 45,9 \%)$. A legtöbben pihenés, kikapcsolódás céljából ritkán végeznek fizikai aktivitással (pulzusszám-emelkedéssel, izzadással) járó 
tevékenységet $(\mathrm{n}=236 ; 51,9 \%)$. A legtöbb válaszadó $(\mathrm{n}=238 ; 52,3 \%)$ naponta egy-két csésze kávét fogyaszt és nem iszik energiaitalt ( $\mathrm{n}=352 ; 77,4 \%)$.

A kérdő́ivet kitöltő felnőttek 44\%-a $(\mathrm{n}=200)$ szerint jó az egészségi állapota, $71,9 \%-\mathrm{a}(\mathrm{n}=327)$ nem jelzett krónikus betegséget. Az alvásminőséghez szorosan kapcsolódó nyugtalanláb-szindróma (rest legs syndrome RLS) a kitöltók 2,6\%-át $(n=12)$ érinti.

A pszichoszomatikus panaszok közül legtöbben a kimerültséget jelölték (átlag: 7,34), míg a legritkábban a hasmenés fordult elő (átlag: 1,37). Az összes pszichoszomatikus panasz havi előfordulási száma átlagosan 26,72 (tehát szinte minden napra jutott legalább egy panasz).

\section{Alvásminoosség}

Az alvásminőség vizsgálatakor a válaszadók átlagosan 5,08 pontot értek el az Athén Insomnia Skálán (minimum: 0; maximum: 19; SD: 3,88), amely esetén minél magasabb a pont, annál nagyobb fokú az alvászavar, 10 ponttól már insomniáról beszélünk. A kérdőívet kitöltók $13,4 \%$-a $(\mathrm{n}=61)$ tartozik ebbe a kategóriába. A napi alvásmennyiség átlagosan 6,8 óra (minimum: 1 ; maximum: 11; SD: 1,19). Az alvászavar leggyakoribb okai a válaszadók szerint: munkahelyi stressz $(\mathrm{n}=162 ; 35,6 \%)$,

1. táblázat $\mid A z$ alvásproblémák okai a válaszadók szerint $(\mathrm{n}=455)$

\begin{tabular}{llcc}
\hline Az alvásproblémák okai & $\mathrm{n}$ & $\%$ \\
\hline 1. Munkahelyi stressz & 162 & 35,6 \\
2. Magánéleti stressz & 161 & 35,4 \\
3. Fájdalom & 110 & 24,2 \\
4. Iskola, tanulás & 106 & 23,3 \\
5. Zaj & 75 & 16,5 \\
6. Kényelmetlen ágy & 69 & 25,2 \\
7. Váltott múszakos munkavégzés & 66 & 14,5 \\
8. Pszichés betegségek & 58 & 12,7 \\
9. Kisgyermek egy háztartásban, aki gyakran & 47 & 10,3 \\
felébreszti & & \\
10. Emésztórendszeri panaszok & 37 & 8,1 \\
11. Egyéb & 19 & 4,2 \\
\hline
\end{tabular}

2. táblázat | Elalvási nehézség esetén alkalmazott szokások $(\mathrm{n}=455)$

\begin{tabular}{llcc}
\hline Elalvási nehézség esetén alkalmazott szokások & $\mathrm{n}$ & $\%$ \\
\hline 1. & Tévét néz & 237 & 52,1 \\
2. & Olvas & 150 & 33 \\
3. Zenét hallgat & 88 & 19,3 \\
4. Imádkozik & 51 & 11,2 \\
5. Meditál & 51 & 11,2 \\
6. & Egyéb & 37 & 8,1 \\
& (például táblagéppel, telefonnal játszik) & & \\
\hline
\end{tabular}

3. táblázat | Elalvást segítő készítmények alkalmazása $(\mathrm{n}=455)$

\begin{tabular}{llcc}
\hline Elalvást segítő megoldások & $\mathrm{n}$ & $\%$ \\
\hline 1. Gyógyteát iszik & 52 & 11,4 \\
2. Altatót vesz be & 34 & 7,5 \\
3. Gyógynövény-eredetü készítményt vesz be & 19 & 4,2 \\
4. Alkoholt iszik & 19 & 4,2 \\
5. Homeopátiás készítményt vesz be & 11 & 2,4 \\
\hline
\end{tabular}

magánéleti stressz $(\mathrm{n}=161 ; 35,4 \%)$ és fájdalom $(\mathrm{n}=$ $110 ; 24,2 \%)$ (1. táblázat).

Felmértük, mit tesznek a megkérdezettek nehéz elalvás esetén, azaz mi segít nekik az elalvásban. A legtöbben tévét néznek $(\mathrm{n}=237 ; 52,1 \%)$ és/vagy olvasnak $(\mathrm{n}=$ $150 ; 33 \%)$ és/vagy zenét hallgatnak $(\mathrm{n}=88 ; 19,3 \%)$ (2. táblázat).

Elalvási nehézség esetén a válaszadók $11,4 \%$-a $(\mathrm{n}=52)$ gyógyteát iszik, 7,5\%-a $(\mathrm{n}=34)$ pedig altatószert alkalmaz (3. táblázat).

\section{Az alvásminöséget befolyásoló tényezők}

Az alvás hosszát befolyásolja a válaszadók életkora, azaz az idősebbek kevesebbet alszanak $(\mathrm{p}=0,001)$, valamint az, hogy a válaszadó dolgozik-e, és ha nem, miért nem $(\mathrm{p}=0,021)$. A tanulók több órát alszanak (átlag: 7,12 óra), mint a dolgozók (átlag: 6,74 óra; $\mathrm{p}=0,011$ ) és a nyugdíjasok (átlag: 6,48 óra; $\mathrm{p}=0,005$ ). Felmértük, hogy az ápolók mennyit alszanak $(\mathrm{n}=59$; átlag: 6,38 óra) más szakmák képviselőihez képest; eredményeink szerint az irodai munkát végzók ( $\mathrm{n}=88$; átlag: 6,89 óra; $\mathrm{p}=0,06)$, a pedagógusok $(\mathrm{n}=5 \mathrm{l}$; átlag: 6,96 óra; $\mathrm{p}=$ $0,08)$ és más egészségügyi dolgozók ( $\mathrm{n}=21$; átlag: 7,10 óra; $\mathrm{p}=0,028$ ) is többet alszanak az ápolóknál.

Az alvás mennyiségével összefüggésben van az alvásminőség, azaz aki rosszabb értéket kapott az Athén Insomnia Skálán, kevesebbet alszik $(r=0,32 ; B=-1,045$; $\mathrm{p}<0,001)$.

Eredményeink szerint az egészség-magatartás befolyásolja az alvás minőségét. Aki azt vallotta, hogy egészségesen táplálkozik, kevesebb pontot ért el a skálán, azaz jobb az alvásminősége, mint az egészségtelenül táplálkozóknak $(\mathrm{p}<0,001)$ (1. ábra). A rendszeres testmozgás is jótékony az alvásra $(\mathrm{p}=0,011)$ (2. ábra).

Az insomnia összefügg a kávéfogyasztással $(\mathrm{p}=0,045)$, ugyanis az insomniás válaszadók $21,7 \%$-a minimum napi három csésze kávét fogyaszt, akiknek azonban jó az alvásminősége, ott ez az arány $10 \%$. Igazolódott ez a skálán elért átlagpontok összehasonlításakor is, azaz a nem kávézók ( $\mathrm{n}=129$; AIS: 4,84 pont) és a napi három csészével fogyasztók alvásminősége eltér ( $\mathrm{n}=52$; AIS: 6,29 pont; $\mathrm{p}=0,036$ ).

Akiknek nincs krónikus megbetegedésük $(\mathrm{n}=327$; AIS: 4,76), jobb az alvásminőségük, mint akiknek van krónikus betegsége $(\mathrm{n}=121$; AIS: 6,$07 ; \mathrm{p}=0,001)$ (3. ábra). A pszichoszomatikus panaszok gyakorisága is 


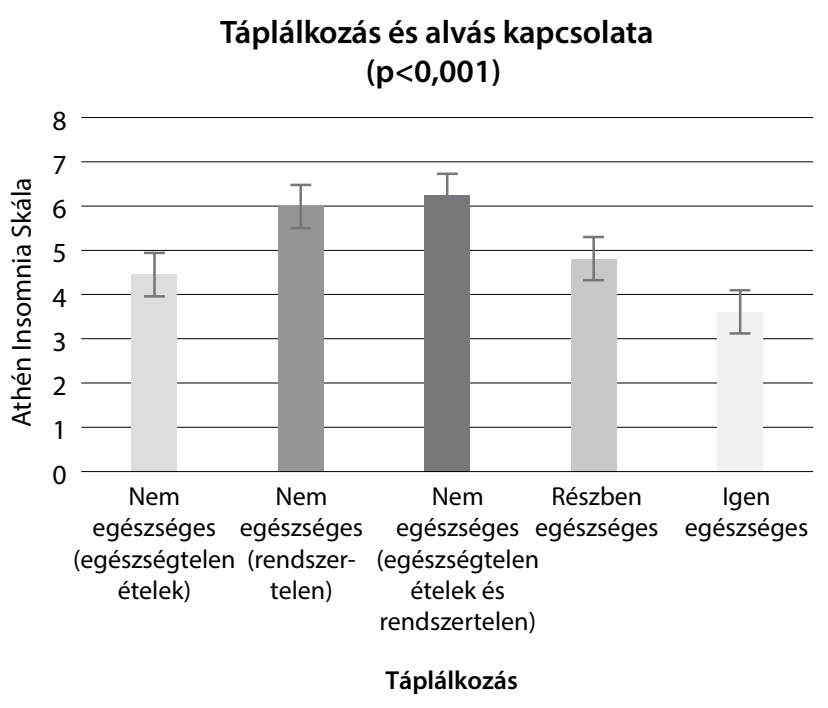

1. ábra | A táplálkozás és az alvásminőség kapcsolata $(\mathrm{n}=455)$

\section{Rendszeres testmozgás jótékony hatása az alvásminőségre \\ $(p=0,011)$}

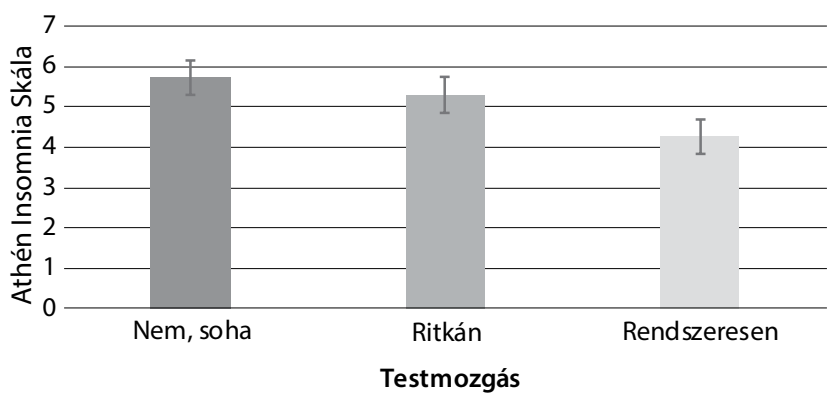

2. ábra | A testmozgás és az alvásminőség kapcsolata $(\mathrm{n}=455)$

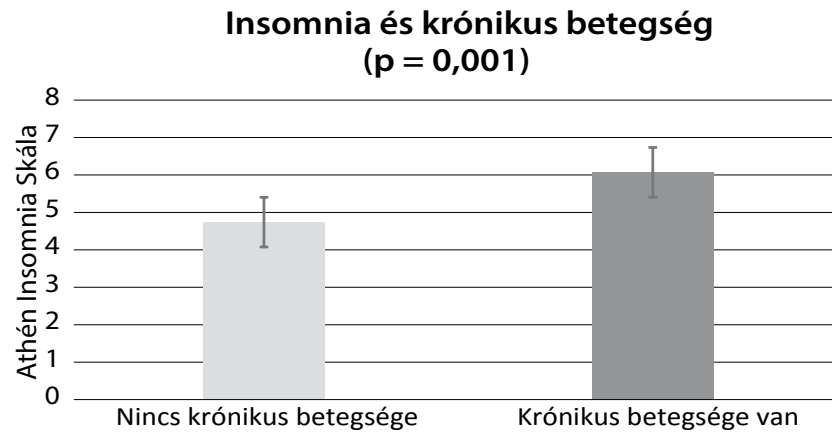

3. ábra $\mid$ Az insomnia és a krónikus betegségek kapcsolata $(\mathrm{n}=455)$

összefügg az alvásminőséggel, a kapcsolat a lineáris regresszió szerint gyenge pozitív $(\mathrm{r}=0,54 \mathrm{l} ; \mathrm{B}=0,076$, $\mathrm{p}<0,001)$; valamint akik jobban alszanak, az egészségi állapotukat is jobbnak ítélik ( $\mathrm{p}<0,001)$.

Az AIS alapján igazolódott a magánéleti stressz ( $\mathrm{p}=$ $0,001)$ és fájdalom hatása $(\mathrm{p}=0,033)$ az alvásminőségre, azaz aki bejelölte alvást befolyásoló tényezónek a fentie- ket, magasabb pontot ért el az Athén Insomnia Skálán. Továbbá, aki a szorongást jelölte alvásproblémájának okaként, rosszabb alvásminőséget tapasztalt $(\mathrm{n}=58$, AIS: 7,41, p<0,001).

A gyógyteát és altatót alkalmazók alvásminősége roszszabb, mint a más elalvást segítő megoldást alkalmazóké $(\mathrm{p}=0,001$ és $\mathrm{p}<0,001)$.

A nók nagyobb arányban olvasnak $(\mathrm{n}=129 ; 37,9 \%)$ elalvási nehézség esetén, mint a férfiak $(n=21 ; 18,3 \%$; $\mathrm{p}<0,001)$. Akik egyedül élnek, kisebb arányban olvasnak $(\mathrm{p}=0,017)$. A gyermeket nevelők $(\mathrm{p}=0,033)$ és a magasabb iskolai végzettségứek többen válaszolták $(\mathrm{p}<0,001)$, hogy az olvasás segít az elalvásban.

\section{Megbeszélés}

A válaszadók (átlagéletkor: 38,56 év) átlagosan 6,8 órát alszanak naponta, a kor emelkedésével ez csökken ( $\mathrm{p}=$ $0,001)$. Kripke és munkatársainak vizsgálatában napi 7 óra alvás esetén találták a legkisebb mortalitási rizikót, az ennél kevesebb vagy több órát alvókhoz képest [13].

A válaszadók átlagosan 5,08 pontot értek el az Athén Insomnia Skálán (minimum: 0; maximum: 19; SD: $3,88)$. A skálán elért 10 ponttól már insomniáról beszélünk, a minta 13,4\%-a (n=61) tartozik ebbe a kategóriába. Az Athén Insomnia Skála alkalmazásával Magyarországon a „Hungarostudy 2002” epidemiológiai felmérés során vizsgálták reprezentatív, 12643 fös mintán az insomniás panaszok gyakoriságát. 2002-ben jobb alvásminőségről számoltak be a válaszadók (AIS-átlag: $3 \pm 0,04$ ), az insomnia kategóriába is kevesebben tartoztak $(9,2 \%)$ $[8,14]$.

$\mathrm{Az}$ insomniát befolyásolja a kávéfogyasztás $(\mathrm{p}=$ $0,045)$, a táplálkozás minősége $(\mathrm{p}<0,001)$ és a fizikai aktivitás $(\mathrm{p}=0,011)$, azaz a pozitív egészség-magatartás jótékony hatással van az alvásra. Az alvásminőség és egészség-magatartás összefüggését vizsgálták más kutatók is hasonló eredményekkel [15-17].

A rosszabb alvásminőség összefüggésben van a krónikus betegségek $(\mathrm{p}=0,001)$ és a pszichoszomatikus panaszok gyakoriságával $(\mathrm{p}<0,001)[3,6,8]$. Vizsgálatunk szerint az ápolók kevesebbet alszanak más szakmák képviselőinél. Az egészségügyi dolgozók alvásproblémáival számos kutatás foglalkozik a váltott múszak okozta cirkadiánritmus-zavar miatt $[18,19]$.

$\mathrm{Az}$ alvászavar leggyakoribb okai: munkahelyi stressz $(35,6 \%)$, magánéleti stressz $(35,4 \%)$ és fájdalom $(24,2 \%)$. $\mathrm{Az}$ AIS alapján igazolódott a magánéleti stressz ( $\mathrm{p}=$ $0,001)$ és fájdalom hatása $(\mathrm{p}=0,033)$. Zeitlhofer osztrák felmérésében is hasonló okokat neveztek meg leggyakrabban: személyes problémák (23\%), a nap eseményei (22\%), fájdalom (16\%), munkahelyi problémák (13\%) [20].

Az elalvást segítő legnépszerúbb módszerek: tévénézés $(52,1 \%)$, olvasás $(33 \%)$, zenehallgatás $(19,3 \%)$. Kutatások rámutattak arra, hogy a tévénézés, számítógéphasználat káros elalvás előtt, ugyanis megnehezíti az 
elalvást és a pihentetô alvást. Gradisar és munkatársainak eredményei is ezt támasztják alá, azonban a megkérdezett amerikai lakosok 60\%-a tévét néz az elalvást megelőző órában [11]. Érdekes eredmény, hogy az általunk megkérdezett felnőttek nagy része, amikor nehezen alszik, a tévét hívja segítségül.

Elalvási nehézség esetén a válaszadók 7,5\%-a alkalmaz altatószert. A gyógyteát és altatót alkalmazók alvásminősége rosszabb, mint a más módszert alkalmazóké $(\mathrm{p}=$ $0,001$ és $\mathrm{p}<0,001)$.

Március 13-án, az Alvás Világnapján az Alvásdiagnosztikai és Terápiás Világszövetség (World Association of Sleep Medicine - WASM) a pihentető alvás fontosságát hangsúlyozta, jelen vizsgálatunkkal mi is szeretnénk erre felhívni a figyelmet [21]

Anyagi támogatás: A közlemény megírása, illetve a kapcsolódó kutatómunka anyagi támogatásban nem részesült.

Szerzői munkamegosztás: F. K.: Hipotézisek kidolgozása, kérdőív összeállítása, vizsgálat lefolytatása, statisztikai elemzés, a kézirat megszövegezése. F. B.: Hipotézisek kidolgozása, kérdő́ív összeállítása, a szakirodalmi áttekintés. P. D.: Kérdőív összeállítása, a kézirat megszövegezése. S. N.: Kérdőív kiosztása, adatbázis készítése. O. A.: Hipotézisek kidolgozása, a kézirat megszövegezése. A cikk végleges változatát valamennyi szerző elolvasta és jóváhagyta.

Anyagi érdekeltség: A szerzőknek nincsenek érdekeltségeik.

\section{Köszönetnyilvánítás}

Köszönjük minden résztvevőnek, aki kitöltötte a kérdőívet.

\section{Irodalom}

[1] Taylor, D. J., Lichstein, K. L., Durrence, H. H.: Insomnia as a health risk factor. Behav. Sleep Med., 2003, I(4), 227-247.

[2] Choueiry, N., Salamoun, T., Jabbour, H., et al.: Insomnia and relationship with anxiety in university students: A Cross Sectional Designed Study. PLoS ONE, 2016, 11(2), e0149643.

[3] Purebl, Gy., Bódizs, R.: Insomnia and its comorbidity with mental disorders and somatic diseases. [Az insomnia komorbiditása egyéb betegségekkel.] Gyógyszerészet, 2008, 52(6), 323-328. [Hungarian]

[4] Wannamethee, S. G., Papacosta, O., Lennon, L., et al.: Self-reported sleep duration, napping, and incident heart failure: prospective associations in the British Regional Heart Study. J. Am. Geriatr. Soc., 2016, 64(9), 1845-1850.

[5] Meng, L., Zheng, Y., Hui, R.: The relationship of sleep duration and insomnia to risk of hypertension incidence: a meta-analysis of prospective cohort studies. Hypertens. Res., 2013, 36(11), 985-995.

[6] Irwin, M. R.: Why sleep is important for health: A psychoneuroimmunology perspective. Annu. Rev. Psychol., 2015, 66, 143172.

[7] Ohayon, M. M.: Epidemiology of insomnia: what we know and what we still need to learn. Sleep Med. Rev., 2002, 6(2), 97111.

[8] Novák, M.: Sleep disorders and quality of life. Doctoral dissertation. [Alvászavarok és életminőség. Doktori értekezés.] Budapest, 2004. [Hungarian]

[9] Kikuchi, ., Ishii, N.: The relationship between self-awareness of fatigue symptoms and working conditions in female nurses. Sangyo Eiseigaku Zasshi, 2015, 57(5), 230-240.

[10] Purebl, Gy., Bánki, M. Cs, Novák, M., et al.: Insomnia - diagnostic and therapeutic guide. [Insomnia - diagnosztikus és terápiás útmutató. Szakmai irányelvtervezet.] In: Németh A. (ed.). Pszichiátriai Útmutató, 2010. Medition Kiadó, Budapest, 2010. [Hungarian]

[11] Gradisar, M., Wolfson, A. R., Harvey, A. G., et al.: The sleep and technology use of Americans: findings from the National Sleep Foundation's 2011 Sleep in America Poll. J. Clin. Sleep Med., 2013, 9(12), 1291-1299.

[12] Soldatos, C. R., Dikeos, D. G., Paparrigopoulos, T. J.: Athens Insomnia Scale: validation of an instrument based on ICD-10 criteria. J. Psychosom. Res., 2000, 48(6), 555-560.

[13] Kripke, D. F., Garfinkel, L., Wingard, D. L., et al.: Mortality associated with sleep duration and insomnia rates. Arch. Gen. Psychiatry, 2002, 59(2), 131-136.

[14] Skrabski, Á., Kopp, M., Kawachi, I.: Social capital in a changing society: cross sectional associations with middle aged female and male mortality. J. Epidemiol. Community Health, 2003, 57(2), 114-119.

[15] Virág, M., Berényi, K., Kiss, I.: Epidemiological investigation of the relationship between insomnia and lifestyle. [Insomnia és az életmód kapcsolatának epidemiológiai vizsgálata.] Magyar Epidemiológia, 2014, 11(1-2) 125-134. [Hungarian]

[16] Wang, J., Yin, G., Li, G., et al.: Efficacy of physical activity counseling plus sleep restriction therapy on the patients with chronic insomnia. Neuropsychiatr. Dis. Treat., 2015, 11, 2771-2778.

[17] Tan, X., Alén, M., Cheng, S. M.: Associations of disordered sleep with body fat distribution, physical activity and diet among overweight middle-aged men. J. Sleep Res., 2015, 24(4), 414-424.

[18] Flo, E., Pallesen, S., Magerøy, N., et al.: Shift work disorder in nurses - Assessment, prevalence and related health problems. PLoS ONE, 2012, 7(4), e33981.

[19] Fusz, K., Tóth, Á., Fullér, N., et al.: Sleep quality of nurses working in shifts - Hungarian adaptation of the Bergen Shift Work Sleep Questionnaire. [Váltott múszakban dolgozó ápolók alvásminőségének vizsgálata a magyar nyelvre adaptált Berger Shift Work Sleep Questionnaire alkalmazásával.] Orv. Hetil., 2015, 156(49), 2003-2008. [Hungarian]

[20] Zeitlhofer, S., Seidel, G., Klösch, D., et al.: Sleep habits and sleep complaints in Austria: current self-reported data on sleep behaviour, sleep disturbances and their treatment. Acta Neurol. Scand., 2010, 122(6), 398-403.

[21] World Sleep Day. http://wasmonline.org/world-sleep-day [Letöltve: 2016. 08. 01.]

(Oláh András dr., Pécs, Vörösmarty u. 4., 7621 e-mail: andras.olah@etk.pte.hu) 